\title{
Pengaruh Penerapan E-Filing pada Kepatuhan Wajib Pajak Badan dengan Biaya Kepatuhan Pajak sebagai Variabel Moderasi
}

\author{
Kadek Katon Pranata ${ }^{1}$ \\ Ni Luh Supadmi ${ }^{2}$ \\ ${ }^{1}$ Fakultas Ekonomi dan Bisnis Universitas Udayana (Unud), Bali, Indonesia \\ email: katonpranata@gmail.com/ Telp: +6281916255895 \\ ${ }^{2}$ Fakultas Ekonomi dan Bisnis Universitas Udayana (Unud), Bali, Indonesia
}

\begin{abstract}
ABSTRAK
Penelitian ini bertujuan untuk menguji pengaruh penerapan $e$-filing pada kepatuhan wajib pajak badan dengan biaya kepatuhan pajak sebagai variabel moderasi di KPP Pratama Tabanan. Populasi penelitian ini adalah seluruh wajib pajak badan yang terdaftar di KPP Pratama Tabanan tahun 2016. Metode penentuan sampel yang digunakan adalah non probability sampling dengan teknik purposive sampling. Jumlah sampel yang digunakan sebanyak 42 wajib pajak badan. Pengumpulan data dilakukan dengan menyebarkan kuesioner kepada responden dan diukur dengan skala likert. Metode analisis data dilakukan dengan regresi linear sederhana dan Moderated Regression Analysis (MRA). Hasil penelitian menunjukkan bahwa variabel penerapan $e$-filing berpengaruh positif pada kepatuhan wajib pajak badan, sedangkan biaya kepatuhan pajak tidak mampu memoderasi pengaruh penerapan $e$ filing pada kepatuhan wajib pajak badan di KPP Pratama Tabanan

Kata Kunci: E-filing, kepatuhan wajib pajak, biaya kepatuhan
\end{abstract}

\section{ABSTRACT}

The purposes of this study are to determine the effect of application of e-filling system on the corporate taxpayers compliance with tax compliance costs as a moderating in The Tabanan Tax Office. The population of the study was corporate taxpayers registered in The Tabanan Tax Office in 2016. The sampling method used non probability sampling with purposive sampling technique. Total of the samples were 42 corporate taxpayers. The datas were collected by questionnaire that have been distributed to the respondents and measured by likert scale. The datas analysis method used simple linear regression and moderated regression analysis.the result of th study shown that the application of e-filing system have a positive and significant effect on the corporate taxpayers compliance, while the tax compliance cost can not moderated the effect of the application of e-filing system on corporate taxpayers compliance in The Tabanan Tax Office.

Keywords: E-filing, taxpayers compliance, compliance cost

\section{PENDAHULUAN}

Negara Indonesia sebagai negara yang sedang berkembang membutuhkan anggaran yang besar untuk dapat menjalankan segala program pembangunan yang dirancang pemerintah. Semakin besar pengeluaran pemerintah dalam rangka pembiayaan suatu negara, maka akan semakin besar penerimaan negara yang 
dibutuhkan. Sumber penerimaan negara dibagi menjadi 2 (dua) yaitu pendapatan dalam negeri dan pinjaman luar negeri. Sumber penerimaan negara yang berasal dari dalam negeri dapat dibedakan menjadi 3 (tiga) yaitu Penerimaan Negara Bukan Pajak (PNBP), penerimaan pajak dan hibah.

Pendapatan pajak menjadi sumber penerimaan yang penting baik di negara maju maupun negara berkembang (Alabede et al., 2011). Sumber penerimaan negara dari pajak telah menjadi sumber pendapatan utama dalam kehidupan suatu negara, yaitu untuk menunjang kegiatan perekonomian, menggerakan roda pemerintahan, subsidi bagi masyarakat dan pembangunan infrastruktur serta penyediaan fasilitas umum bagi masyarakat. Menurut Menteri Keuangan, pajak mendominasi penerimaan kas negara dengan rata-rata sebesar 78,5 persen dalam Anggaran Pendapatan dan Belanja Negara (APBN). Sedangkan penerimaan negara bukan pajak sebesar 21,1 persen dan sisanya 0,4 persen dari hibah. Penerimaan dari pajak juga mengalami peningkatan setiap tahunnya, seperti disajikan pada Tabel 1. berikut.

Tabel 1.

Perkembangan Penerimaan Negara Tahun 2012-2016

(dalam Triliun Rupiah)

\begin{tabular}{ccccccc}
\hline & \multicolumn{2}{c}{ Penerimaan Pajak } & \multicolumn{2}{c}{$\begin{array}{c}\text { Penerimaan Negara } \\
\text { Bukan Pajak (PNBP) }\end{array}$} & \multicolumn{2}{c}{ Hibah } \\
\cline { 2 - 7 } Tahun & $\begin{array}{c}\text { Realisasi } \\
\text { APBN }\end{array}$ & $\%$ & $\begin{array}{c}\text { Realisasi } \\
\text { APBN }\end{array}$ & $\%$ & $\begin{array}{c}\text { Realisasi } \\
\text { APBN }\end{array}$ & \% \\
\hline 2012 & 980,5 & 73,3 & 351,8 & 26,3 & 5,8 & 0,4 \\
2013 & $1.077,3$ & 74,9 & 354,8 & 24,7 & 6,8 & 0,5 \\
2014 & $1.146,9$ & 74,0 & 398,6 & 25,7 & 5,0 & 0,3 \\
2015 & $1.240,4$ & 82,3 & 255,6 & 16,9 & 12,0 & 0,8 \\
2016 & $1.539,2$ & 86,2 & 245,1 & 13,7 & 2,0 & 0,1 \\
Jumlah & $\mathbf{5 9 8 4 , 3}$ & $\mathbf{7 8 , 5}$ & $\mathbf{1 6 0 5 , 9}$ & $\mathbf{2 1 , 1}$ & $\mathbf{3 1 , 6}$ & $\mathbf{0 , 4}$ \\
\hline Sumber : BPS, 2017 & & & & &
\end{tabular}


Prawirasuta (2016) menyatakan penerimaan pajak sebagai sumber utama APBN digunakan untuk menjalankan program di berbagai sektor pemerintahan dan kemakmuran rakyat, mulai dari sektor pendidikan, kesehatan, industri, pertanian, maupun perbankan. Besarnya peran pajak dalam APBN, pemerintah dalam hal ini Direktorat Jenderal Pajak melakukan berbagai usaha untuk meningkatkan penerimaan pajak.

Reformasi sistem perpajakan menjadi satu langkah pemerintah dalam upaya meningkatkan penerimaan pajak. Pada tahun 1984 pemerintah melakukan reformasi sistem perpajakan dengan mengubah sistem perpajakan dari Official Assessment System menjadi Self Assessment System. Self Assessment System memberikan kepercayaan penuh kepada wajib pajak untuk menghitung, memperhitungkan, menyetor, dan melaporkan seluruh pajak yang menjadi kewajibannya (Supadmi, 2009). Efektifnya penerapan Self Assessment System bergantung dari kesukarelaan dan kepatuhan dari wajib pajak.

Kepatuhan wajib pajak menjadi faktor penting dalam merealisasikan target penerimaan pajak. Semakin tinggi tingkat kepatuhan wajib pajak, maka pendapatan pajak juga akan semakin tinggi, dan sebaliknya. Kepatuhan wajib pajak diidentifikasi dari kepatuhan dalam mendaftarkan diri, melaporkan Surat Pemberitahuan (SPT), menghitung, dan membayar pajak terutang serta tunggakan pajak (Rohmawati, 2012). Susmita (2016) menyatakan isu mengenai kepatuhan perpajakan menjadi hal penting karena ketidakpatuhan perpajakan yang besar dapat menimbulkan upaya penghindaran pajak, seperti tax evasion dan tax avoidance, yang berakibat pada berkurangnya penerimaan kas negara dari pajak. 
Menteri Keuangan menyebutkan, pada tahun 2016 rasio kepatuhan wajib pajak hanya mencapai 63,15 persen. Dari 32,77 juta wajib pajak yang terdaftar, hanya sebesar 20,17 juta wajib pajak yang telah melaporkan SPT. Capaian rasio kepatuhan ini juga masih berada di bawah target yang telah ditetapkan dalam Rencana Strategis Kementerian Keuangan 2015-2019, dimana setiap tahunnya diharapkan ada kenaikan target kepatuhan sebesar 2,25 persen, dari 70 persen di tahun 2015 hingga 80 persen di tahun 2019. Hal ini menunjukkan bahwa kepatuhan wajib pajak masih rendah.

Jurnal Paying Taxes 2016 yang diterbitkan dari hasil kerjasama World Bank dan Pricewaterhouse Coopers, menjelaskan bahwa kepatuhan wajib pajak akan terwujud apabila ada kemudahan dalam membayar pajak. Direktorat Jenderal Pajak yang memiliki tugas dalam meningkatkan kepatuhan wajib pajak akan berusaha untuk meningkatkan pelayanan pajaknya. Salah satu upayanya adalah dengan melakukan perbaikan sistem administrasi perpajakan dengan memanfaatkan teknologi informasi dan komunikasi yaitu dengan diluncurkannya sistem e-filing, berdasarkan Keputusan Direktur Jenderal Pajak Nomor Kep88/PJ/2004.

E-Filing adalah cara pelaporan SPT Tahunan secara online dan real time melalui website Direktorat Jenderal Pajak atau Penyedia Jasa Aplikasi atau Application Service Provider (ASP) yang ditunjuk oleh Dirjen Pajak. Pemanfaatan teknologi informasi dapat mempercepat proses pelayanan dan pemeriksaan, serta menjadikan proses administrasinya menjadi jauh lebih sederhana (Fasmi dan Fauzan, 2014). Kemudahan dalam menggunakan sistem 
teknologi informasi akan menimbulkan perasaan bahwa sistem tersebut memiliki kegunaan, dan karenanya akan menimbulkan rasa nyaman bila bekerja dengan sistem teknologi informasi (Venkatesh dan Davis, 2000). Lembaga perpajakan (Direktorat Jenderal Pajak) meluncurkan $e$-filing pajak sebagai kesempatan untuk dapat meningkatkan sistem perpajakan dan membuatnya lebih sederhana, lebih cepat, dan meminimalisir kesalahan (Fu et al., 2006). Menurut Wiyono dalam Sugihanti (2011), dengan adanya sistem $e$-filing wajib pajak tidak lagi mencetak semua formulir SPT dan menunggu tanda terima secara manual. Ketika wajib pajak telah merasa puas maka akan memberikan dampak positif terhadap sikap patuh wajib pajak tersebut (Dewi 2018). Selain itu, Azmi dan Bee (2010) mengatakan sistem $e$-filing akan menguntungkan baik bagi wajib pajak ataupun fiskus, hanya jika sistem $e$-filing sungguh-sungguh diterapkan oleh wajib pajak.

Penelitian yang dilakukan oleh Nurhidayah (2015) menyatakan bahwa penerapan $e$-filing berpengaruh positif dan signifikan pada kepatuhan wajib pajak di KPP Pratama Klaten. Sedangkan, hasil dari penelitian Abdurrohman dkk. (2015) menunjukkan hasil bahwa implementasi e-filing belum berperan secara optimal dalam peningkatan kepatuhan wajib pajak dan penelitian dari Novita dkk. (2014) menunjukkan bahwa sistem elektronik perpajakan seperti e-filing berpengaruh negatif pada kepatuhan pemenuhan kewajiban perpajakan. Ketidakkonsistenan hasil penelitian terdahulu terkait variabel penerapan $e$-filing ini, maka pengaruh penerapan e-filing pada kepatuhan wajib pajak perlu diteliti kembali dengan menambahkan biaya kepatuhan pajak sebagai variabel pemoderasi. Berdasarkan hasil penelitian dari Tresno dkk. (2013) biaya kepatuhan 
pajak dapat memoderasi pengaruh persepsi penerapan sistem $e$-filing pada tingkat kepatuhan wajib pajak.

Wajib pajak mengeluarkan biaya dalam memenuhi kewajiban perpajakannya yang disebut dengan biaya kepatuhan pajak (compliance cost). Sandford (1973, 1989, 1994, 1995, 2000) dalam Lopes dan Martins (2013) menjelaskan bahwa, tax compliance cost selain sebagai biaya cash money (direct money cost), juga termasuk di dalamnya adalah waktu (time cost), dan pikiran (psychological cost). Kompleksitas dari sistem perpajakan dan ketidakpastian pada hukum pajak akan meningkatkan biaya kepatuhan bagi wajib pajak (Lopes dan Martins, 2013). Semakin tinggi biaya kepatuhan pajak akan membuat wajib pajak enggan untuk membayar kewajiban pajaknya (Susmita, 2016). Reekman dan Gudrun (2010) mengungkapkan perusahaan harus dapat mengatur biaya kepatuhannya karena biaya kepatuhan yang tinggi dapat menghambat investor untuk mau menanamkan modalnya.

Hasil studi oleh World Bank dan Pricewaterhouse Coopers dalam Paying Taxes 2015 dijelaskan, reformasi sistem perpajakan dalam hal dokumentasi secara elektronik seperti $e$-filing dapat menekan biaya kepatuhan yang dikeluarkan wajib pajak dalam memenuhi kewajiban pajaknya. Tinggi rendahnya pembebanan biaya kepatuhan dapat mempengaruhi tingkat kepatuhan wajib pajak yang pada akhirnya berpengaruh pada tingkat penerimaan pajak secara nasional (Anggadewi, 2015). Semakin sedikit biaya kepatuhan yang dikeluarkan akan mendorong wajib pajak untuk memenuhi kewajiban pajaknya. Sebaliknya, apabila semakin besar 
biaya kepatuhan, maka wajib pajak akan cenderung tidak patuh untuk melaporkan pajaknya.

Target kepatuhan pajak nasional yang diharapkan dapat dicapai adalah 72,5 persen untuk masing-masing KPP berdasarkan Surat Edaran Nomor SE07/PJ/2016 mengenai penetapan Target dan Strategi Pencapaian Rasio Kepatuhan Wajib Pajak tahun 2016. KPP Pratama Tabanan dipilih sebagai wilayah penelitian, sebab berdasarkan data yang diperoleh menunjukkan bahwa rasio kepatuhan wajib pajak mengalami fluktuasi dari tahun ke tahun. Tingkat kepatuhan wajib pajak di KPP Pratama Tabanan pada tahun 2012-2016 disajikan pada Tabel 2. berikut.

Tabel 2.

Tingkat Kepatuhan Wajib Pajak di KPP Pratama Tabanan

Tahun 2012-2016

\begin{tabular}{ccccc}
\hline Tahun & $\begin{array}{c}\text { WP } \\
\text { Terdaftar }\end{array}$ & $\begin{array}{c}\text { WP } \\
\text { Efektif }\end{array}$ & $\begin{array}{c}\text { WP yang } \\
\text { menyampaikan } \\
\text { SPT }\end{array}$ & $\begin{array}{c}\text { Rasio } \\
\text { Kepatuhan }\end{array}$ \\
\hline 2012 & 78.975 & 58.635 & 34.917 & $59,55 \%$ \\
2013 & 85.720 & 65.368 & 40.606 & $62,12 \%$ \\
2014 & 93.398 & 73.033 & 43.450 & $59,49 \%$ \\
2015 & 101.598 & 81.222 & 38.891 & $47,88 \%$ \\
2016 & 109.650 & 89.272 & 48.639 & $54,48 \%$ \\
\hline \multicolumn{5}{l}{ Sumber: KPP Pratama Tabanan, 2017 }
\end{tabular}

Berdasarkan Tabel 2. dapat diketahui bahwa rasio kepatuhan wajib pajak di KPP Pratama Tabanan pada tahun 2012-2016 mengalami fluktuasi namun cenderung menurun. Terlihat juga bahwa rasio kepatuhan wajib pajak pada tahun 2016 yaitu sebesar 54.48 persen masih jauh di bawah target kepatuhan pajak nasional yang ditetapkan Direktorat Jenderal Pajak sesuai dengan Surat Edaran Nomor SE-07/PJ/2016, yaitu sebesar 72,5 persen

Penelitian ini menggunakan wajib pajak badan sebagai subjek penelitian. Tabel 3. menunjukkan perbandingan rasio kepatuhan dan penyampaian SPT 
melalui $e$-filing oleh wajib pajak orang pribadi dan wajib pajak badan tahun pajak 2016 di KPP Pratama Tabanan

Tabel 3.

Perbandingan Kepatuhan Wajib Pajak dan Penyampaian SPT melalui E-Filing oleh Wajib Pajak Orang Pribadi dan Wajib Pajak Badan Tahun Pajak 2016 di KPP Pratama Tabanan.

\begin{tabular}{lcc}
\hline \multicolumn{1}{c}{ Keterangan } & WPOP & WP Badan \\
\hline Jumlah wajib pajak efektif & 86.139 & 3.133 \\
jumlah wajib pajak yang & 47.291 & 1.348 \\
menyampaikan SPT & 36.926 & 42 \\
Jumlah SPT melalui $e$-filing & $54,90 \%$ & $43,03 \%$ \\
Rasio kepatuhan & $78,08 \%$ & $3,12 \%$ \\
Persentase penyampaian SPT & & \\
melalui $e$-filing &
\end{tabular}

Sumber: KPP Pratama Tabanan, 2017

Tabel 3. menunjukkan bahwa rasio kepatuhan wajib pajak badan lebih kecil dari wajib pajak orang pribadi. Selain itu, persentase penyampaian SPT melalui e-filing untuk wajib pajak badan masih sangatlah rendah yaitu sebesar 3,12 persen. Data ini menunjukkan bahwa kepatuhan dan penggunaan e-filing untuk wajib pajak badan masih sangat rendah dibanding wajib pajak orang pribadi. Rendahnya tingkat kepatuhan wajib pajak badan dapat dipengaruhi oleh pelaporan wajib pajak badan yang lebih rumit dibanding wajib pajak orang pribadi dan dibutuhkan biaya yang besar apabila harus menyewa konsultan pajak dalam membantu pelaporan pajaknya. Apabila hal ini terus berlanjut, maka penerimaan pajak akan mengalami penurunan. Selain itu, sistem e-filing diciptakan dengan tujuan untuk meningkatkan kepatuhan sukarela bagi wajib pajak dengan memberikan kemudahan dalam melaporkan SPT bagi seluruh wajib pajak termasuk wajib pajak badan, seharusnya sistem e-filing dapat meningkatkan kepatuhan wajib pajak badan. 
Berdasarkan latar belakang tersebut, maka rumusan masalah penelitian ini adalah sebagai berikut: 1) Apakah penerapan $e$-filing berpengaruh pada kepatuhan wajib pajak badan? 2)Apakah biaya kepatuhan pajak memoderasi pengaruh penerapan e-filing pada kepatuhan wajib pajak badan? Adapun tujuan dari penelitian ini adalah untuk menguji pengaruh masing-masing variabel terhadap kepatuhan wajib pajak badan. Kegunaan dari penelitian ini adalah penelitian ini diharapkan dapat memberikan tambahan ilmu pengetahuan, informasi, referensi peneliti lain, dan menjadi masukan dan bahan evaluasi bagi pemerintah dan Direktorat Jenderal Pajak.

Teori yang digunakan dalam penelitian ini adalah Technology Acceptance Model (TAM). TAM menjelaskan tentang pengguna teknologi yang menerima dan menggunakan teknologi tersebut dalam pekerjaan individunya. TAM dikembangkan oleh Davis F.D pada tahun 1985. Tujuan dari TAM adalah untuk menjelaskan sikap individu terhadap pengguna suatu teknologi. Menurut Taylor dan Todd (1995) dalam TAM, niat ditentukan oleh sikap penggunaan teknologi baik secara langsung atau tidak langsung terhadap persepsi kemudahan penggunaan (ease to use) dan kemanfaatan (usefulness) untuk menjelaskan minat pengguna (user's intention). TAM menegaskan bahwa dengan persepsi kemudahan penggunaan (ease to use) dan kemanfaatan (usefulness) dapat menentukan penerimaan teknologi dan menjadi kunci dari niat perilaku pengguna untuk menggunakan teknologi informasi (Lee et al., 2011). Kedua variabel model TAM tersebut dapat menjelaskan aspek keperilakuan pengguna (Davis, 1985). 
Teori TAM diadopsi dari Theory of Reasoned Action (TRA) yang dilakukan oleh Fishbein dan Ajzen (1975) yaitu teori tindakan beralasan dengan premis bahwa sikap dan perilaku seseorang ditentukan dari reaksi dan persepsi orang tersebut terhadap suatu hal (Kirana, 2010). TRA menentukan hubungan antara keyakinan, sikap, dan perilaku (Moore dan Izak, 1996). Pikkarainen et al. (2004), menyatakan TRA terbukti hanya terikat pada konteks yang digunakan, sehingga tidak dapat digeneralisasi. Sedangkan, TAM dengan persepsi kemudahan penggunaan (ease to use) dan persepsi kemanfaatan (usefulness) dapat menjelaskan pengaruh penerimaan sistem informasi. Legris et al. (2001) menyatakan TAM telah terbukti berguna sebagai teori dalam mengetahui dan menjelaskan perilaku pengguna dalam penerapan sistem informasi.

Langkah pemerintah dalam memperbaiki kemudahan pelaporan pajak adalah langkah yang tepat untuk mendorong kepatuhan pajak. Kemudahan penggunaan dan manfaat yang didapat melalui penerapan e-filing akan meningkatkan kepatuhan wajib pajak. Hal ini didukung dengan penelitian dari Nurhidayah (2015), Susmita (2016) dan Kiswara (2016) yang mengungkapkan bahwa penerapan e-filing berpengaruh positif terhadap kepatuhan wajib pajak. Berdasarkan teori TAM dan hasil penelitian sebelumnya, maka hipotesis yang dirumuskan adalah sebagai berikut :

$\mathrm{H}_{1} \quad$ : Penerapan $e$-filing berpengaruh positif pada kepatuhan wajib pajak badan

Penerapan $e$-filing di tengah arus informasi dan teknologi yang semakin berkembang akan menjawab kebutuhan masyarakat khususnya wajib pajak dalam meningkatkan efektivitas dan efisiensi pelaporan pajaknya. Reformasi sistem 
perpajakan dalam hal dokumentasi secara elektronik seperti e-filing dapat menekan biaya kepatuhan yang dikeluarkan wajib pajak. Apabila biaya kepatuhan dikeluarkan dalam pelaporan pajak secara manual tinggi, maka wajib pajak tentu akan lebih memilih untuk menggunakan e-filing dalam pelaporannya. Hal ini didukung dengan penelitian yang dilakukan oleh Tresno dkk (2013) yang menyatakan bahwa biaya kepatuhan dapat memoderasi hubungan antara persepsi penerapan sistem $e$-filing dan tingkat kepatuhan pajak.

$\mathrm{H}_{2}$ : Biaya kepatuhan pajak memperkuat hubungan antara penerapan e-filing pada kepatuhan wajib pajak badan

\section{METODE PENELITIAN}

Metode dalam penelitian ini menggunakan metode pendekatan kuantitatif yang bersifat asosiatif kausal. Wilayah penelitian dilaksanakan di KPP Pratama Tabanan. Objek yang diteliti adalah kepatuhan wajib pajak badan di KPP Pratama Tabanan.

Variabel independen penelitian ini adalah penerapan e-filing. E-Filing adalah sistem penyampaian surat pemberitahuan (SPT) oleh wajib pajak secara elektronik dengan sistem online yang memanfaatkan jaringan internet. Variabel penerapan e-filing diukur dengan indikator yang diadopsi dari penelitian Nurhidayah (2015) dan dikembangkan menjadi 14 butir pernyataan dalam kuesioner. Kepatuhan wajib pajak badan menjadi variabel dependen dalam penelitian ini. Kepatuhan wajib pajak merupakan sikap wajib pajak yang mematuhi segala aturan perpajakan yang berlaku. Variabel kepatuhan wajib pajak badan diukur dengan indikator yang diadopsi dari penelitian Nurhidayah (2015) dan dikembangkan menjadi 8 pernyataan dalam kuesioner. Biaya kepatuhan pajak 
menjadi variabel moderasi dalam penelitian ini. Biaya kepatuhan pajak adalah biaya yang dikeluarkan oleh wajib pajak sebagai tambahan atas kewajiban pajaknya (Jabbar dan Jeff, 2008). Variabel biaya kepatuhan pajak diukur dengan indikator yang diadopsi dari penelitian Andri (2009) dan dikembangkan menjadi 6 pertanyaan dalam kuesioner.

Pengumpulan data dilakukan dengan teknik kuesioner. Skala pengukuran yang digunakan adalah skala likert 4 poin, yaitu sangat tidak setuju diberi skor 1 , tidak setuju diberi skor 2, setuju diberi skor 3, dan sangat setuju diberi skor 4 . Responden dalam penelitian ini adalah wajib pajak badan di KPP Pratama Tabanan yang telah menggunakan $e$-filing.

Populasi dalam penelitian ini adalah seluruh wajib pajak badan yang terdaftar di KPP Pratama Tabanan tahun 2016 dengan jumlah 3.676 wajib pajak badan. Metode penentuan sampelnya adalah non probability sampling dengan teknik purposive sampling yaitu teknik pengambilan sampel dengan pertimbangan tertentu. Kriteria sampel yang digunakan adalah 1) wajib pajak badan di KPP Pratama Tabanan yang efektif pada tahun 2016, 2) wajib pajak badan di KPP Pratama Tabanan yang telah melaporkan SPT pada tahun 2016, 3) wajib pajak badan di KPP Pratama Tabanan yang melaporkan SPT pada tahun 2016 menggunakan e-filing, sehingga diperoleh sampel penelitian berjumlah 42 responden.

Teknik analisis data yang digunakan yaitu uji instrumen penelitian yang terdiri dari uji validitas dan uji reliabilitas. Pengujian asumsi klasik yang dilakukan terdiri dari uji normalitas, uji heterokedastisitas, dan uji 
multikolinearitas. Pengujian pengaruh variabel independen pada variabel dependen dilakukan dengan menggunakan analisis regresi linear sederhana, dengan model regresi sebagai berikut.

$$
\mathrm{Y}=\alpha+\beta \mathrm{X}
$$

Keterangan:

$$
\begin{aligned}
& \mathrm{Y}=\text { subjek dalam variabel dependen yang diprediksikan. } \\
& \alpha=\text { nilai } \hat{Y} \text { ketika nilai } \mathrm{X}=0 \text { (harga konstan) } \\
& \beta=\text { angka arah atau koefisien regresi } \\
& \mathrm{X}=\text { subjek pada variabel independen yang mempunyai nilai tertentu. }
\end{aligned}
$$

Pengujian variabel moderasi dalam mempengaruhi hubungan variabel independen pada variabel dependen dilakukan dengan Moderated Regression Analysis (MRA), dengan model MRA sebagai berikut.

$$
Y=\alpha+\beta_{1} X+\beta_{2} Z+\beta_{3} X \cdot Z+\varepsilon
$$

Keterangan :

$$
\begin{aligned}
& \mathrm{Yi}=\text { Kepatuhan Wajib Pajak } \\
& \alpha=\text { Bilangan Konstanta } \\
& B=\text { Koefisien arah persamaan penelitian } \\
& \mathrm{X}=\text { Penerapan } e \text {-filling } \\
& \mathrm{Z}=\text { variabel moderasi biaya kepatuhan pajak } \\
& \varepsilon=\text { Kesalahan pengganggu }
\end{aligned}
$$

\section{HASIL DAN PEMBAHASAN}

Kuesioner dalam penelitian ini telah disebarkan kepada 42 responden yang menjadi sampel. Semua responden telah memenuhi kriteria sampel yang ditetapkan. Distribusi dan tingkat pengembalian disajikan pada Tabel 4. berikut. 
Tabel 4.

Rincian Penyebaran dan Pengembalian Kuesioner

\begin{tabular}{lr}
\hline \multicolumn{1}{c}{ Keterangan } & Jumlah \\
\hline Kuesioner yang disebar & 42 \\
Kuesioner yang tidak kembali & 4 \\
Kuesioner yang kembali & 38 \\
Kuesioner yang tidak lengkap & - \\
Kuesioner yang digunakan & 38 \\
$\begin{array}{l}\text { Tingkat pengembalian (response rate) } \\
\text { Kuesioner yang kembali x 100\% }\end{array}$ & $90,5 \%$ \\
$\begin{array}{l}\text { Kuesioner yang disebar Xingkat pengembalian yang digunakan (useable response rate) } \\
\text { Kuesioner yang digunakan x 100\% }\end{array}$ & \\
\hline Kuesioner yang kembali & $100 \%$ \\
\hline Sumber : Data diolah, 2018 &
\end{tabular}

Tabel 4. menunjukkan bahwa dari 42 kuesioner yang disebar, kuesioner yang kembali sebanyak 38 kuesioner. Terdapat 4 kuesioner yang tidak kembali dan dianggap gugur. Perhitungan dari data tersebut menunjukkan tingkat pengembalian responden (response rate) sebesar 90,5 persen dengan tingkat pengembalian yang digunakan (useable response rate) sebesar 100 persen.

Berdasarkan profil dari 38 responden yang mengisi kuesioner pada penelitian ini diperoleh karakteristik responden penelitian yang terdiri atas jenis usaha, lama penggunaan $e$-filing, dan jenis SPT yang dilaporkan melalui $e$-filing. Jenis usaha menjelaskan sejauh mana persebaran pengguna $e$-filing dari wajib pajak badan dan lama penggunaan $e$-filing dan jenis SPT yang dilaporkan melalui e-filing menjelaskan pengalaman wajib pajak dalam menggunakan fasilitas $e$ filing untuk pelaporan pajaknya. Data karakteristik responden terdiri atas jenis usaha, lama penggunaan e-filing dan jenis SPT yang dilaporkan melalui $e$-filing disajikan pada Tabel 5. berikut. 
Tabel 5.

Karakteristik Responden

\begin{tabular}{|c|c|c|}
\hline Keterangan & Jumlah & Persentanse (\%) \\
\hline \multicolumn{3}{|l|}{ Jenis Usaha } \\
\hline Manufaktur & 5 & $13,16 \%$ \\
\hline Perdagangan/Jasa & 30 & $78,95 \%$ \\
\hline Perbankan & - & - \\
\hline Lainnya & 3 & $7,89 \%$ \\
\hline Total & 38 & $100,00 \%$ \\
\hline \multicolumn{3}{|l|}{ Lama Penggunaan } \\
\hline$<1$ tahun & 17 & $44,74 \%$ \\
\hline 1-3 tahun & 15 & $39,47 \%$ \\
\hline$>3$ tahun & 6 & $15,79 \%$ \\
\hline Total & 38 & $100,00 \%$ \\
\hline \multicolumn{3}{|l|}{ Jenis SPT yang Dilaporkan } \\
\hline $\mathrm{PPh}$ & 18 & $47,37 \%$ \\
\hline PPh dan PPN & 19 & $50,00 \%$ \\
\hline PPh, PPN, dan PPnBM & 1 & $2,63 \%$ \\
\hline Total & 38 & $100,00 \%$ \\
\hline
\end{tabular}

Berdasarkan Tabel 5. bahwa mayoritas responden bergerak pada usaha perdagangan/jasa yaitu sebanyak 30 responden atau sebesar 78,95 persen dan sisanya adalah manufaktur (13,16 persen) dan jenis usaha lainnya $(7,89$ persen $)$. berdasarkan lama penggunaan e-filing dari 38 responden yang didapat sebagai sampel, mayoritas lama penggunaan $e$-filing adalah $<1$ tahun (kurang dari satu tahun) dengan responden sebanyak 17 atau sebesar 44,74 persen. Berdasarkan jensi SPT yang dilaporkan, mayoritas SPT yang dilaporkan melalui layanan $e$ filing adalah PPh dan PPN dengan jumlah responden sebanyak 19 atau sebesar 50,00 persen.

Statistik deskriptif bertujuan untuk memberikan gambaran mengenai karakteristik variabel yang diteliti, yang meliputi jumlah sampel, nilai minimum, nilai maksimum, nilai rata-rata, dan standar deviasi dari masing-masing variabel 
penelitian. Hasil statistik deskriptif dalam penelitian ini dapat dilihat pada Tabel 6. berikut.

Tabel 6.

Hasil Statistik Deskriptif

\begin{tabular}{lrrrrr}
\hline & N & Minimum & Maximum & Mean & Std. Deviation \\
\hline E-Filing & 38 & 1 & 4 & 2,68 & 0,451 \\
Patuh & 38 & 1 & 4 & 2,98 & 0,374 \\
Biaya & 38 & 1 & 4 & 2,90 & 0,496 \\
\hline Valid N (listwise) & 38 & \multicolumn{7}{c}{} \\
\hline Sumber: Data diolah, 2018 & \multicolumn{7}{c}{}
\end{tabular}

Tabel 6. menunjukkan variabel penerapan $e$-filing memiliki nilai minimum sebesar 1 dan nilai maksimum sebesar 4. Rata-rata dari variabel penerapan $e$-filing sebesar 2,68 dan standar deviasi sebesar 0,451. Variabel kepatuhan wajib pajak badan memiliki nilai minimum 1 dan nilai maksimum 4 rata-rata dari variabel kepatuhan wajib pajak badan sebesar 2,98 dan standar deviasi sebesar 0,374. Variabel biaya kepatuhan pajak memiliki nilai minimum 1 dan nilai maksimum 4. Rata-rata dari variabel biaya kepatuhan pajak sebesar 2,90 dan standar deviasi sebesar 0,496 .

Uji validitas digunakan untuk menguji ketepatan dan kecermatan alat ukur dalam melakukan fungsi ukurnya. Kuesioner sebagai alat ukur dapat dikatakan valid apabila $r_{\text {hitung }}$ lebih besar dari $r_{\text {tabel }}(0,3202)$ dari 38 responden yang merupakan jumlah sampel (N) . Hasil uji validitas variabel penerapan e-filing (X), kepatuhan wajib pajak (Y), dan biaya kepatuhan pajak (Z) dapat dilihat pada Tabel 7. berikut ini. 
Tabel 7.

Hasil Uji Validitas

\begin{tabular}{llccc}
\hline \multicolumn{1}{c}{ Variabel } & Item Pernyataan & $\mathbf{r}_{\text {hitung }}$ & $\mathbf{r}_{\text {tabel }}$ & Keterangan \\
\hline Penerapan E-Filing & E-Filing 1 & 0,481 & 0,320 & Valid \\
(X) & E-Filing 2 & 0,633 & 0,320 & Valid \\
& E-Filing 3 & 0,892 & 0,320 & Valid \\
& E-Filing 4 & 0,770 & 0,320 & Valid \\
& E-Filing 5 & 0,843 & 0,320 & Valid \\
& E-Filing 6 & 0,347 & 0,320 & Valid \\
& E-Filing 7 & 0,370 & 0,320 & Valid \\
& E-Filing 8 & 0,576 & 0,320 & Valid \\
& E-Filing 9 & 0,409 & 0,320 & Valid \\
& E-Filing 10 & 0,635 & 0,320 & Valid \\
E-Filing 11 & 0,793 & 0,320 & Valid \\
Pajak Badan (Y) & E-Filing 12 & 0,677 & 0,320 & Valid \\
& E-Filing 13 & 0,810 & 0,320 & Valid \\
& E-Filing 14 & 0,550 & 0,320 & Valid \\
& Patuh 1 & 0,567 & 0,320 & Valid \\
& Patuh 2 & 0,568 & 0,320 & Valid \\
& Patuh 3 & 0,700 & 0,320 & Valid \\
& Patuh 4 & 0,584 & 0,320 & Valid \\
Pajaya Kepatuhan Z) & Patuh 5 & 0,455 & 0,320 & Valid \\
& Patuh 6 & 0,422 & 0,320 & Valid \\
& Patuh 7 & 0,695 & 0,320 & Valid \\
& Patuh 8 & 0,616 & 0,320 & Valid \\
& Biaya 1 & 0,677 & 0,320 & Valid \\
& Biaya 2 & 0,792 & 0,320 & Valid \\
& Biaya 3 & 0,689 & 0,320 & Valid \\
& Biaya 5 & 0,576 & 0,320 & Valid \\
& Biaya 6 & 0,697 & 0,320 & Valid \\
& 0,381 & 0,320 & Valid \\
\hline Sumber: Data diolah & & &
\end{tabular}

Sumber: Data diolah, 2018

Hasil uji validitas pada Tabel 7. menunjukkan bahwa nilai $r_{\text {hitung }}$ lebih besar dari $\mathrm{r}_{\text {tabel }}$ ini memiliki arti bahwa seluruh butir pernyataan dinyatakan valid dan layak digunakan sebagai instrumen untuk mengukur variabel penelitian.

Uji reliabilitas dilakukan untuk memberikan gambaran sejauh mana alat ukur dapat memberikan hasil yang konsisten, apabila digunakan dua kali atau lebih dengan gejala yang sama. Reliabelnya alat ukur dapat dibuktikan dengan nilai Cronbach Alpha sama dengan atau lebih besar dari 0,7. Hasil uji reliabilitas ditunjukkan pada Tabel 8 . berikut. 
Tabel 8.

Hasil Uji Reliabilitas

\begin{tabular}{lcc}
\hline \multicolumn{1}{c}{ Variabel } & Nilai Cronbach's Alpha & Keterangan \\
\hline Penerapan E-Filing (X) & 0,841 & Reliabel \\
Kepatuhan Wajib Pajak Badan (Y) & 0,709 & Reliabel \\
Biaya Kepatuhan Pajak (Z) & 0,702 & Reliabel \\
\hline
\end{tabular}

Sumber: Sumber: Data diolah, 2018

Hasil uji reliabilitas pada Tabel 8. menunjukkan butir pernyataan dari variabel penerapan $e$-filing, kepatuhan wajib pajak badan, dan biaya kepatuhan pajak memiliki nilai Cronbach's Alpha lebih besar dari 0,7, hal ini memiliki arti seluruh variabel adalah reliabel atau handal dan seluruh butir-butir pernyataan dapat digunakan untuk penelitian selanjutnya.

Uji normalitas dilakukan untuk menguji adanya variabel pengganggu atau residual dalam model regresi yang memiliki distribusi normal. Untuk mendeteksi normalitas data, dapat dilakukan uji statistik non-parametrik KolmogorovSmirnov Test (K-S), dengan ketentuan nilai probabilitas signifikan K-S $\geq 5$ persen atau 0.05, maka data dikatakan berdistribusi normal. Hasil uji normalitas ditunjukkan pada Tabel 9. berikut

Tabel 9.

Hasil Uji Normalitas

\begin{tabular}{|c|c|c|}
\hline & & Unstandardized Residual \\
\hline $\mathrm{N}$ & & 38 \\
\hline \multirow{3}{*}{ Normal Parameters ${ }^{\mathrm{a}, \mathrm{b}}$} & Mean & $0 \mathrm{E}-7$ \\
\hline & Std. Deviation & 2,20085473 \\
\hline & Absolute & 0,178 \\
\hline \multirow[t]{2}{*}{ Most Extreme Differences } & Positive & 0,178 \\
\hline & Negative & $-0,073$ \\
\hline Kolmogorov-Smirnov Z & & 1,096 \\
\hline Asymp. Sig. (2-tailed) & & 0,181 \\
\hline
\end{tabular}

Berdasarkan Tabel 9. terlihat bahwa nilai signifikansi 0,181 yang berarti lebih besar dari 0,05 maka dapat dikatakan bahwa data berdistribusi normal. 
Uji multikolinearitas menguji model regresi apakah ditemukan adanya korelasi antar variabel bebas. Jika nilai toleransi lebih dari 0,1 dan atau VIF kurang dari 10, maka dapat dikatakan tidak ada multikolinearitas. Hasil pengujian multikolinearitas dapat dilihat pada Tabel 10. berikut.

Tabel 10.

Hasil Uji Multikolinearitas

\begin{tabular}{lccl}
\hline \multicolumn{1}{c}{ Variabel } & Tolerance & VIF & \multicolumn{1}{c}{ Keterangan } \\
\hline Penerapan E-Filing & 0,992 & 1,008 & $\begin{array}{l}\text { Tidak terjadi } \\
\text { multikolinearitas }\end{array}$ \\
Biaya Kepatuhan Pajak & 0,992 & 1,008 & $\begin{array}{l}\text { Tidak terjadi } \\
\text { multikolinearitas }\end{array}$ \\
\hline
\end{tabular}

Sumber: Data diolah, 2018

Berdasarkan Tabel 10. dapat dijelaskan bahwa semua variabel bebas mempunyai nilai Tolerance $\geq 0,10$ dan nilai VIF $\leq 10$. Dapat disimpulkan bahwa seluruh variabel bebas dalam penelitian ini tidak terjadi multikolinieritas.

Uji heteroskedastisitas menguji apakah terjadi ketidaksamaan varians dari variabel absolute residual pengamatan ke pengamatan yang lain dalam suatu model regresi. Tingkat signifikansi yang berada di atas 0,05 menunjukkan model regresi dikatakan bebas dari masalah heteroskedastisitas. Hasil pengujian heteroskedastisitas dapat dilihat pada Tabel 4.10 berikut.

Tabel 11.

\section{Hasil Uji Heterokedastisitas}

\begin{tabular}{lcl}
\hline \multicolumn{1}{c}{ Variabel } & Sig. & \multicolumn{1}{c}{ Keterangan } \\
\hline Penerapan E-Filing & 0,908 & $\begin{array}{l}\text { Tidak terjadi } \\
\text { heteroskedastisitas } \\
\text { Biaya Kepatuhan Pajak }\end{array}$ \\
$\begin{array}{lll}\text { Tidak terjadi } \\
\text { heteroskedastisitas }\end{array}$ \\
\hline Sumber: Data diolah, 2018 & &
\end{tabular}


Berdasarkan Tabel 11. dapat diketahui bahwa nilai signifikansi dari semua variabel yang diteliti mempunyai nilai signifikansi lebih besar dari 0,05, maka dapat disimpulkan bahwa dalam model regresi ini tidak terjadi heterokedastisitas.

Analisis regresi linear sederhana dilakukan untuk menguji pengaruh satu variabel bebas terhadap variabel terikat. Analisis regresi linear sederhana digunakan untuk menganalisis pengaruh penerapan e-filing (X) pada kepatuhan wajib pajak badan (Y). Hasil analisis regresi linear sederhana disajikan pada Tabel 12. berikut.

Tabel 12.

Hasil Regresi Linear Sederhana

\begin{tabular}{|c|c|c|c|c|c|c|}
\hline \multirow[b]{2}{*}{ Model } & & \multicolumn{2}{|c|}{ Unstandardized Coefficients } & \multirow{2}{*}{$\begin{array}{c}\begin{array}{c}\text { Standardized } \\
\text { Coefficients }\end{array} \\
\text { Beta }\end{array}$} & \multirow[b]{2}{*}{ l } & \multirow[b]{2}{*}{ Sig. } \\
\hline & & B & Std. Error & & & \\
\hline 1 & $(\mathrm{Col}$ & 12,263 & 2,284 & & 5,369 & 0,000 \\
\hline & E-Filing & 0,308 & 0,060 & 0,651 & 5,139 & 0,000 \\
\hline
\end{tabular}

Sumber: Data diolah, 2018

Pada Tabel 12. hasil perhitungan regresi linear sederhana dengan menggunakan program SPSS 20 didapat hasil sebagai berikut:

$$
Y=12,263+0,308 X
$$

Nilai konstanta sebesar 12,263 menunjukkan bahwa bila penerapan e-filing (X) sama dengan nol, maka nilai kepatuhan wajib pajak badan akan meningkat sebesar 12,263 satuan. Nilai koefisien $\beta=0,308$ menunjukkan bahwa bila nilai penerapan $e$-filing meningkat satu satuan, maka nilai dari kepatuhan wajib pajak badan akan meningkat sebesar 0,308 satuan.

Penelitian ini menggunakan Moderated Regression Analysis (MRA) dalam model persamaan regresi untuk mengetahui kemampuan biaya kepatuhan pajak (Z) dalam memoderasi pengaruh penerapan e-filing (X) pada kepatuhan wajib 
pajak badan (Y). Hasil pengujian Moderated Regression Analysis (MRA) disajikan pada Tabel 13. berikut:

Tabel 13.

Hasil Moderated Regression Analysis

\begin{tabular}{|c|c|c|c|c|c|c|}
\hline \multirow[b]{2}{*}{ Model } & & \multicolumn{2}{|c|}{ Unstandardized Coefficients } & \multirow{2}{*}{\begin{tabular}{|c|}
$\begin{array}{c}\text { Standardized } \\
\text { Coefficients }\end{array}$ \\
Beta
\end{tabular}} & \multirow[b]{2}{*}{$\mathbf{t}$} & \multirow[b]{2}{*}{ Sig. } \\
\hline & & B & Std. Error & & & \\
\hline & (Constant) & $-0,834$ & 14,174 & & $-0,059$ & 0,953 \\
\hline & E-Filing & 0,584 & 0,393 & 1,231 & 1,483 & 0,147 \\
\hline & Biaya & 0,775 & 0,812 & 0,770 & 0,954 & 0,347 \\
\hline 1 & E-Filing.Biaya & $-0,016$ & 0,022 & $-0,876$ & $-0,729$ & 0,471 \\
\hline
\end{tabular}

Pada Tabel 13. hasil perhitungan Moderated Regression Analysis (MRA) dengan menggunakan program SPSS 20 didapat hasil sebagai berikut:

$$
Y=-0,834+0,584 X+0,775 Z-0,016 X \cdot Z+\varepsilon
$$

Nilai konstanta sebesar -0,834 menunjukkan bahwa bila penerapan e-filing $(\mathrm{X})$, biaya kepatuhan pajak (Z), dan interaksi penerapan e-filing dengan biaya kepatuhan pajak (X.Z) sama dengan nol, maka kepatuhan wajib pajak badan akan menurun sebesar 0,834 satuan. Nilai koefisien $\beta_{3}=-0,016$ memiliki arti bahwa bila interaksi antara penerapan e-filing (X) dengan biaya kepatuhan pajak (Z) meningkat satu satuan, maka kepatuhan wajib pajak badan (Y) akan menurun sebesar 0,016 satuan.

Analisis Koefisien Determinasi digunakan untuk mengukur seberapa besar kemampuan semua variabel bebas dalam menerangkan variasi dari variabel dependennya (Ghozali, 2016:95). Hasil koefisien determinasi $\left(\mathrm{R}^{2}\right)$ ditunjukkan pada Tabel 14. sebagai berikut. 
Tabel 14.

Hasil Uji Koefisien Determinasi

\begin{tabular}{lrrrr}
\hline Model & R & R Square & $\begin{array}{c}\text { Adjusted R } \\
\text { Square }\end{array}$ & $\begin{array}{c}\text { Std. Error of } \\
\text { the Estimate }\end{array}$ \\
\hline 1 &, $683^{\mathrm{a}}$ &, 467 &, 420 & 2,278 \\
\hline Sumber: & Data diolah, 2018 & & &
\end{tabular}

Nilai adjusted $R$ square yang ditunjukkan pada Tabel 14. sebesar 0,420. Artinya variabel penerapan e-filing (X), biaya kepatuhan pajak (Z) dan interaksi antara variabel penerapan e-filing dan biaya kepatuhan pajak (X.Z) mampu menjelaskan 42 persen variasi yang ada pada variabel Kepatuhan Wajib Pajak Badan (Y). Sisanya sebesar 58 persen dijelaskan oleh faktor-faktor lain yang tidak masuk dalam penelitian.

Uji Kelayakan Model (Uji F) bertujuan untuk menguji apakah model yang digunakan dalam penelitian ini layak atau tidak untuk digunakan sebagai alat analisis dalam menguji pengaruh variabel independen pada variabel dependennya. Hasil uji F pada ditunjukkan pada Tabel 15. sebagai berikut.

Tabel 15.

Hasil Uji Kelayakan Model (Uji F)

\begin{tabular}{llrrrrr}
\hline Model & & Sum of Squares & df & Mean Square & F & Sig. \\
\hline 1 & Regression & 154,591 & 3 & 51,530 & 9,929 &, $000^{\mathrm{b}}$ \\
& Residual & 176,461 & 34 & 5,190 & & \\
& Total & 331,053 & 37 & & & \\
\hline
\end{tabular}

Sumber: Data diolah, 2018

Tabel 15. menunjukkan bahwa nilai $F$ hitung sebesar 9,929 dengan signifikansi $\mathrm{F}$ atau $\mathrm{P}$ value 0,000 lebih kecil dari $\alpha=0,05$, maka dapat disimpulkan bahwa variabel penerapan $e$-filing dan biaya kepatuhan pajak mampu memprediksi atau menjelaskan kepatuhan wajib pajak badan di KPP Pratama Tabanan. 
Uji hipotesis (uji statistik t) bertujuan untuk melihat ada tidaknya pengaruh variabel bebas (penerapan e-filing) dan variabel pemoderasi (biaya kepatuhan pajak) terhadap variabel terikat (kepatuhan wajib pajak badan). Uji statistik $t$ menjawab hipotesis yang dikembangkan di dalam penelitian ini. Dasar pengambilan keputusan yang digunakan pada uji t yaitu jika signifikansi nilai probabilitas $(\mathrm{P}-$ value $)>0,05$ maka hipotesis ditolak, sedangkan jika signifikansi nilai probabilitas $(\mathrm{P}-$ value $) \leq 0,05$ maka hipotesis diterima.

Hipotesis pertama $\left(\mathrm{H}_{1}\right)$ pengaruh penerapan e-filing pada kepatuhan wajib pajak badan. Berdasarkan Tabel 12. diketahui bahwa signifikansi variabel penerapan $e$-filing sebesar 0,000 lebih kecil dari 0,05 sehingga $\mathrm{H}_{1}$ diterima, hal ini memiliki arti bahwa penerapan e-filing berpengaruh signifikan pada kepatuhan wajib pajak badan. Nilai koefisien regresi penerapan e-filing (X) sebesar 0,308 menunjukkan adanya pengaruh positif penerapan $e$-filing pada kepatuhan wajib pajak badan. Semakin baik sistem penerapan $e$-filing akan menyebabkan semakin tinggi tingkat kepatuhan wajib pajak badan. Wajib pajak badan yang telah menggunakan e-filing merasakan manfaat dalam mempermudah pelaporan pajak, sehingga wajib pajak cenderung untuk ingin melaporkan pajak yang merupakan kewajibannya. Semakin banyak wajib pajak yang sadar untuk melaporkan pajak maka semakin meningkat kepatuhan wajib pajak. Tingginya tingkat kepatuhan, maka akan meningkatkan pendapatan negara dari sektor pajak. Hasil penelitian ini mengkonfirmasi teori TAM, dimana persepsi kemanfaatan (usefulness) dan kemudahan penggunaan (ease to use) yang dirasakan oleh wajib pajak badan dalam menggunakan e-filing mampu meningkatkan kepatuhan sukarela wajib 
pajak badan. Hasil penelitian ini sesuai dengan penelitian yang dilakukan oleh Nurhidayah (2015), Susmita (2016) dan Kiswara (2016) yang mengungkapkan bahwa penerapan e-filing dapat meningkatkan kepatuhan wajib pajak. Baiknya sistem e-filing diharapkan dapat memberikan kepuasan bagi wajib pajak terkait pelayanan yang didapatnya sehingga kepatuhan wajib pajak pun akan meningkat.

Hipotesis kedua $\left(\mathrm{H}_{2}\right)$ yaitu pengaruh penerapan e-filing pada kepatuhan wajib pajak badan dengan biaya kepatuhan pajak sebagai variabel moderasi. Berdasarkan Tabel 13. diketahui bahwa signifikansi interaksi antara variabel penerapan $e$-filing dan biaya kepatuhan pajak (X.Z) sebesar 0,471 lebih besar dari 0,05 sehingga $\mathrm{H}_{2}$ ditolak, hal ini memiliki arti bahwa biaya kepatuhan pajak tidak mampu memoderasi pengaruh penerapan e-filing pada kepatuhan wajib pajak badan. Hasil ini tidak mendukung hipotesis yang diajukan bahwa biaya kepatuhan pajak memperkuat hubungan antara penerapan e-filing pada kepatuhan wajib pajak badan. Hal tersebut disebabkan meskipun wajib pajak badan telah menerapkan e-filing namun mereka masih tetap mengeluarkan biaya untuk melaporkan pajaknya. Biaya yang dikeluarkan seperti biaya untuk menyewa konsultan pajak, biaya dalam mencetak dokumen, biaya internet, dan dampak psikologis yang dirasakan wajib pajak apabila melakukan kesalahan atau mengajukan keberatan atas besarnya pajak yang terutang. Hasil penelitian ini didukung oleh teori TAM yang menjelaskan bahwa selama individu merasa bermanfaat dalam menyelesaikan tugas-tugasnya, mereka akan berniat untuk menggunakan teknologi tersebut. Sehingga meskipun masih ada biaya kepatuhan dalam upaya pelaporan pajak, wajib pajak akan tetap menerima sistem $e$-filing 
karena manfaat yang dirasakannya. Namun biaya kepatuhan pajak tetap menjadi alasan atas kepatuhan pajak yang tidak memuaskan, karena itu perlu adanya penyederhanaan sistem pajak (Mahangila, 2017). Hasil penelitian ini berlawanan dengan hasil penelitian dari Tresno, dkk. (2013) yang menyatakan biaya kepatuhan dapat memoderasi hubungan antara persepsi penerapan sistem $e$-filing dengan tingkat kepatuhan pajak. Hasil yang berbeda kemungkinan disebabkan oleh adanya perbedaan wilayah penelitian dan sampel yang diteliti.

\section{SIMPULAN}

Simpulan dalam penelitian ini adalah sebagai berikut: 1) penerapan e-filing berpengaruh positif pada kepatuhan wajib pajak badan di KPP Pratama Tabanan. Hal ini menjelaskan bahwa semakin baik sistem penerapan e-filing, maka kepatuhan wajib pajak badan juga akan semakin meningkat; 2) biaya kepatuhan pajak tidak dapat memoderasi pengaruh penerapan $e$-filing pada kepatuhan wajib pajak badan di KPP Pratama Tabanan. Hal ini menjelaskan bahwa ada atau tidaknya biaya kepatuhan pajak yang dikeluarkan wajib pajak badan tidak mempengaruhi diterapkannya $e$-filing untuk meningkatkan kepatuhan wajib pajak badan dalam pelaporan pajaknya.

Berdasarkan kesimpulan tersebut di atas, maka peneliti dapat memberikan beberapa saran sebagai berikut: 1) Direktorat Jenderal Pajak agar dapat melakukan perbaikan sistem $e$-filing dan pelatihan penerapan $e$-filing sehingga wajib pajak dapat dengan mudah untuk mempelajari dan menggunakan sistem $e$ filing. Dirjen Pajak perlu memberikan sosialisasi bagi wajib pajak untuk meningkatkan jumlah wajib pajak yang menggunakan e-filing; 2) bagi peneliti 
selanjutnya diharapkan dapat menambahkan variabel lain yang terkait dengan variabel kepatuhan wajib pajak dan dapat mencari lokasi dan sampel penelitian yang berbeda. Hal ini terkait dengan keterbatasan sampel dalam penelitian ini karena jumlah wajib pajak badan pengguna $e$-filing masih sangat sedikit.

\section{REFERENSI}

Abdurrohman, Sisilia., Tjahjanulin Domai., dan Muhammad Shobaruddin. 2015. Implementasi E-Filling dalam Upaya Peningkatan Kepatuhan Wajib Pajak Orang Pribadi (Studi pada Kantor Pelayanan Pajak Pratama Bojonegoro). Jurnal Administrasi Publik, Vol 3(5), 807-811.

Alabede, James O, Zaimah Zainol Ariffin, dan Kamil Md Idris. 2011. Individual Taxpayers' Attitude and Compliance Behaviour in Nigeria: The Moderating Role of Financial Condition and Risk Preference. Journal of Accounting and Taxation, Vol 3(5), 91-104.

Andri, Parwito. 2009. Analisis Atas Pengaruh Pemanfaatan Sistem E-Filing Terhadap Cost of Compliance. Tesis Fakultas Ekonomi Ilmu Sosial dan Ilmu Politik Departemen Ilmu Administrasi Program Pascasarjana Universitas Indonesia.

Anggadewi, Anissa. 2015. Pengaruh Pemahaman Pajak dan Biaya Kepatuhan (Compliance Cost) terhadap Tingkat Kepatuhan Wajib Pajak (Survei pada Kantor Pelayanan Pajak Pratama Bandung Karees). Skripsi Sarjana Program Studi Akuntansi Fakultas Ekonomi Universitas Widyatama, Bandung.

Azmi, A. C. dan Bee, N. L. 2010. The Acceptance of the e-Filing System by Malaysian Taxpayers : A Simplified Model. Electronic Journal of $e$ Government, 8(1), 13-22.

Davis, F. D. 1985. A Technology Acceptance Model for Empirically Testing New End-User Information System: Theory and Results. PhD Thesis Massachusetts Institute of Technology.

Departemen Keuangan. 2016. Data Realisasi Penerimaan Negara (Triliun Rupiah), 2007-2017. Diunduh 10 Juli 2017 di : http://www.bps.go.id.

Dewi, Luh Putu Santi Krisna dan Ni Ketut Lely Aryani M. 2018. Pengaruh Kesadaran Wajib Pajak, Sanksi Perpajakan, E-Filing, dan Tax Amnesty terhadap Kepatuhan Pelaporan Wajib Pajak. E-Jurnal Akuntansi Vol.22(2), $1626-1655$ 
Direktorat Jenderal Pajak. 2016. Laporan Kinerja Direktorat Jenderal Pajak 2016. Jakarta : DJP

Fasmi, Lasnofa dan Fauzan Misra. 2014. Modernisasi Sistem Administrasi Perpajakan dan Tingkat Kepatuhan Pengusaha Kena Pajak. Jurnal Akuntansi Multiparadigma Vol. 5(1)

Fishbein, Martin dan Icek Ajzen. 1975. Belief, Attitude, Intention, and Behavior: An Introduction to Theory and Research.

Fu, Jen-Ruei, Cheng-Kiang Farn, dan Wen-Pin Chao. 2006. Acceptance of Electronic Tax Filing: A Study of Taxpayers Intentions. Information \& Management Vol. 43(1), 109-126.

Ghozali, Imam. 2016. Aplikasi Analisis Multivariate Dengan Program IBM SPSS 21. Badan Penerbit Universitas Diponegoro, Semarang.

Jabbar, Hijattulah Abdul dan Jeff Pope. 2008. The Effects of The Self-Assessment System on The Tax Compliance Costs of Small and Medium Enterprises in Malaysia. Australian Tax Forum, 23, 289.

Kirana, Gita Gowinda. 2010. Analisis Perilaku Penerimaan Wajib Pajak Terhadap Penggunaan E-Filing (Kajian Empiris di Wilayah Kota Semarang). 2010. Skripsi Fakultas Ekonomi Universitas Diponegoro, Semarang.

Kiswara, Danar dan I Ketut Jati. 2016. Pengaruh Penerapan E-Filing dan Peran Account Representative terhadap Pencitraan Otoritas Pajak dan Kepatuhan Wajib Pajak. E-Jurnal Akuntansi Vol. 15(1), 349-377

Lee, Yi-Hsuan, Yi-Chuan Hsieh, dan Chia-Ning Hsu. 2011. Adding Innovation Diffusion Theory to the Technology Acceptance Model: Supporting Employees Intentions to Use E-Learning Systems. Educational Technology \& Society14 (4), 124-137

Legris, Paul, John ingham, dan Pierre Collerette. 2001. Why Do People Use Information Technology? A Critical Review of The Technology Acceptance Model. Information \& Management 40, 191-204.

Lopes, Cidalia dan Antonio Martins. 2013. The Psychological Costs of Tax Compliance : Some Evidence from Portugal. Journal of Applied Business and Economics, Vol. 14(2).

Mahangila, Deogratius Ng'winula. 2017. The Impact of Tax Compliance Costs on Tax Compliance Behaviour. Journal of Tax Administration Vol 3:1. 
Moore, Gary C. dan Izak Benbasat. 1996. Integrating Diffusion of Innovations and Theory of Reasoned Action Models to Predict Utilization of Information Technology by End-Users. Diffusion and Adoption of Information Technology. Springer, Boston, MA, 132-146.

Novita, Anastasia Rizqa. 2014. Pengaruh Efektivitas Penyuluhan, Penerapan Aplikasi Sistem Elektronik Perpajakan, dan Pemeriksaan Pajak Terhadap Tingkat Kepatuhan Pemenuhan Kewajiban Perpajakan (Studi pada KPP Pratama Surabaya Wonocolo). Jurnal Mahasiswa Perpajakan 3(1)

Nurhidayah, Sari. 2015. Pengaruh Penerapan Sistem e-Filing terhadap Kepatuhan Wajib Pajak dengan Pemahaman Internet Sebagai Variabel Pemoderasi pada KPP Pratama Klaten. Skripsi Sarjana Universitas Negeri Yogyakarta.

Pikkarainen, Tero, K. Pikkarainen, H. Karjaluoto, dan S. Pahnila. 2004. Consumer Acceptance of Online Banking: an extension of The Technology Acceptance Model. Internet Research, 14(3), 224-235.

Prawirasuta, Made Wisnu dan Putu Ery Setiawan. 2016. Integritas sebagai Pemoderasi Pengaruh Sanksi Pajak dan Kesadaran pada Kepatuhan Wajib Pajak Orang Pribadi. E-Jurnal Akuntansi Universitas Udayana, Vol. 16(2)

Reekmans, Catherine dan Gudrun Simoens. 2010. How High are The Tax Compliance Costs for Belgian SMEs. Dissertation Faculty of Economic and Business Ghent University.

Rohmawati, A Nur dan Ni Ketut Rasmini. 2012. Pengaruh Kesadaran, Penyuluhan, Pelayanan, dan Sanksi Perpajakan pada Kepatuhan Wajib Pajak Orang Pribadi. E-Jurnal Akuntansi, Vol 1(2).

Sugihanti, Wina Titis. 2011. Analisis Faktor-Faktor yang Mempengaruhi Minat Perilaku Wajib Pajak untuk Menggunakan e-Filing. Skripsi Sarjana Fakultas Ekonomi Universitas Diponegoro, Semarang.

Supadmi, Ni Luh 2009. Meningkatkan kepatuhan wajib pajak melalui kualitas pelayanan. Jurnal Ilmiah Akuntansi dan Bisnis, 4(2).

Susmita, Putu Rara dan Ni Luh Supadmi. 2016. Pengaruh Kualitas Pelayanan, Sanksi Perpajakan, Biaya Kepatuhan Pajak, dan Penerapan E-Filling pada Kepatuhan Wajib Pajak. E-Jurnal Akuntansi, Vol 14(2), 1239-1269.

Taylor, Shirley, dan Peter A. Todd. 1995. Understanding Information Technology Usage: A Test of Competing Models. Information systems research, 6(2), 144-176. 
Tresno, Indra Pahala dan Selvy Ayu Rizky. 2012. Pengaruh Persepsi Penerapan Sistem e-Filing terhadap Tingkat Kepatuhan Wajib Pajak Badan Perilaku Wajib Pajak sebagai Variabel Intervening dan Biaya Kepatuhan Pajak sebagai Variabel Moderasi (Studi Kasus pada Kantor Pelayanan Pajak Pratama Pulogadung Jakarta Timur). Prosiding Simposium Nasional Perpajakan 4 pada Fakultas Ekonomi Negeri Jakarta.

Venkatesh, Viswanath dan Fred D. Davis. 2000. A Theoretical Extension of The Technology Acceptance Model: Four Longitudinal Field Studies. Management Science, Vol. 46(2), 186-204.

World Bank Group dan Pricewaterhouse Coopers. 2015. Paying Taxes 2015. United Kingdom: PwC. 2016. Paying Taxes 2016. United Kingdom : PwC. 